\title{
EDITORIAL
}

Aun a pesar del turismo chino que invade las calles de las grandes capitales en su desenfreno por el consumo de marcas de lujo, a pesar de que el comercio chino se ha apoderado de muchos establecimientos hasta hace poco regentados por personas de aquí, a pesar de que el gigante asiático se ha convertido en el principal tenedor extranjero de deuda pública de Estados Unidos, superando a Japón, China es todavía un país que, para el mundo occidental, encierra más incógnitas que certezas y proyecta al exterior más sospechas que confianzas.

A ciencia cierta no se puede asegurar que las noticias que nos llegan de China, si no provienen de corresponsalías de medios occidentales, sean veraces y partan de intenciones objetivas. Las razones no son atribuibles solo a la opacidad tradicional de la Administración china sino a las divergencias culturales que nos impiden una mirada hacia este país desprovista de prejuicios y folclóricos clichés.

Este número destinado a aportar una brizna de luz acerca de los rasgos específicos del paisaje mediático chino en los campos de la prensa escrita, la televisión y las redes nos revela, como afirma el especialista en cultura china, el profesor Manel Ollé, a la sazón coordinador de la edición, un escenario marcado por las paradojas propias del sistema chino, donde conviven una economía de mercado con un fuerte componente estatal, y con un régimen político de Partido Único, en un capitalismo de estado o un socialismo de mercado.

China es capaz de armonizar contradicciones impensables en el modelo de estado occidental, partiendo de este postulado, surge este número de Communication Papers, con la finalidad de aunar investigaciones importantes sobre el papel que ejercen los medios de comunicación chinos en la generación de la opinión occidental.

Sin ánimo de incurrir en falsa modestia, el equipo editorial de Cp está muy orgulloso de la calidad de la contribuciones que participan en esta publicación porque cree que cumple con creces el objetivo que perseguíamos cuando nos propusimos lanzar el call for papers sobre la opinión occidental construida por los mensajes que nos llegan de los medios chinos.

Espero que lo disfruten.

\section{Carmen Echazarreta}

Universitat de Girona 